\title{
JERMY TIBOR SZEKVENCIÁLIS EVOLÚCIÓJÁNAK ELISMERÉSE
}

\section{AN APPRECIATION OF TIBOR JERMY'S SEQUENTIAL EVOLUTION}

\author{
Szentesi Árpád \\ az MTA doktora, nyugalmazott egyetemi docens, Eötvös Loránd Tudományegyetem Természettudományi Kar \\ szentesi@caesar.elte.hu
}

\begin{abstract}
ÖSSZEFOGLALÁS
Külföldi tudósok által szervezett szekcióülésen méltatták Jermy Tibor akadémikus szekvenciális evolúció hipotézisét, amely a koevolúciós elmélettel szemben a növényevő rovarok és tápnövényeik evolúciós kapcsolatát nem reciprok kölcsönhatásnak, hanem olyan folyamatnak tartja, amelyben a rovarok pusztán követik tápnövényeik megváltozását.
\end{abstract}

\section{ABSTRACT}

As an appretiation of Tibor Jermy's sequential evolution, foreign scientists organized a session within a symposium held in Hungary. Sequential evolution, in opposition with co-evolution, states that herbivorous insects have not been driving the evolution of their host-plants, but merely follow it.

Kulcsszavak: növényevő rovarok, tápnövények, evolúció, koevolúció, szekvenciális evolúció

Keywords: herbivorous insects, host-plants, evolution, co-evolution, sequential evolution

Jelentős adósságot törlesztett a nemzetközi tudós közösség, amikor a 34. Kémiai Ökológia Nemzetközi Szimpóziuma (ISCE'1) keretében, egy szekcióülés során, melyet Anurag A. Agrawal professzor (Cornell Egyetem) szervezett, Jermy Tibor akadémikus tudományos eredményeiről emlékezett meg. A 2014-ben elhunyt tudós a növényevő rovarok és gazdanövényeik evolúciós kapcsolatának kérdéséhez jelentős elméleti hozzájárulást tett, melyet a szekcióüléssel kívántak elismerni. A szekció címe Tibor Jermy's Legacy in Insect-Plant Evolution volt, amelyen tíz előadó vett részt, akik más-más jelentős aspektusát emelték ki Jermy evolúciós elméletének.

${ }^{1}$ ISCE: International Symposium of Chemical Ecology, melyet 2018. augusztus 12-18. között Magyarország rendezett Tóth Miklós, az MTA rendes tagja vezetésével. 
Az 1950-es évektől Vincent Dethier ún. fagostimuláns elmélete uralkodott, amely a növényekben elöforduló serkentő hatású ingeranyagokat tekintette meghatározónak a növényevő rovarok tápnövény választásakor. Másfelől, Gottfried S. Fraenkel (1959) egy nagyhatású közleményben azt hangsúlyozta, hogy a növényekben előforduló másodlagos anyagcsere-termékek (alkaloidok, fenolok, glükozidák, cianogén anyagok stb.) jelenlétének oka a növényeket fogyasztó szervezetek elleni védelem. Nem sokkal később, 1964-ben közölte Paul R. Ehrlich és Peter Raven (E\&R) (1964) egyes lepkefajok és tápnövényeik evolúciós kapcsolatára vonatkozó elképzeléseit, melyet napjainkig a szélesebb értelemben vett terület egyik legjelentősebb közleményének tartanak. Ebben - ugyan meglehetősen bonyolult folyamatként - a két résztvevő, a rovar és a növény kapcsolatát koevolúcióként jelölték meg, amelyben a Fraenkel-féle felfogás jelentős szerepet kapott. A koevolúciós kapcsolat gondolata azóta más tudományos területeket is meghódított, és egyszerübb fogalmazásban azt fejezi ki, hogy két, kapcsolatban lévő faj reciprok hatás formájában, kölcsönösen befolyásolja egymás evolúcióját. Ehrlich és Raven feltételezték, hogy a növények - kedvező mutációk alapján - új kémiai védelmi anyagokat termelnek, melyek eredményeként „,megszöknek” rovarellenségeik elöl, és egy ún. adaptív zónába jutnak, ahol verseny és környezeti sajátosságok következtében jelentős fajképződés (radiáció) zajlik le. Később a rovarfajok is olyan genetikai változásokon (fajképződésen) mennek át, melyek lehetővé teszik számukra az új növényfajokon való táplálkozást (végül is a korábbiakkal rokon növényfajokra telepednek). A modell szerint tehát a filogenetikai fán a két részt vevő élőlénycsoportban jelentős megegyezés (kongruencia) lesz látható: a rokon növényfajokon rokon rovarfajok találhatók.

A gondolat rendkívül vonzó, mert a természet és az emberi civilizáció fejlődéséről is holisztikus képet közvetít (Lenton et al., 2004). Könyvtárnyi szakirodalom, publikációk ezrei keletkeztek, melyek a fenti indirekt, tehát egyáltalán nem közvetlen és nem reciprok kölcsönhatásban keletkező evolúciós kapcsolatot sematizálva, koevolúciónak neveztek el minden szorosnak látszó táplálkozási viszonyt (növényevés, ragadozás, kölcsönösség, parazitizmus), sajnos komolyabb meggondolások nélkül. A 'koevolúció' divatszóvá vált, és valódi tartalmát mellőzve használták. Az 1990-es évekre jelentős fogalmi zavar uralkodott, amelyet napjainkra ugyan nagyjából tisztáztak, azonban a kifejezés jelenlegi használatából is ítélve kétséges, hogy elég széles körben egyértelművé vált-e. A félreértések elkerülésére az eredeti E\&R-modellt elnevezték „megszökés és radiáció” változatnak, melyben kospeciáció zajlik kongruens kladogramokat képezve, míg a manapság koevolúciónak nevezett folyamat olyan reciprok kölcsönhatást jelent, amely a felek közvetlen kapcsolatában valósul meg, és koadaptációt hoz létre, de nem jár fajképződéssel. Látható, hogy a választóvonal a mikro- és makroevolúció közötti különbségben fedezhetö fel. Az azonban nehéz kérdés, hogy a mikroevolúciós változásokból (valamikor) hogyan lesz makroevolúciós állapot. 
A hazai tudományos körökben kevéssé ismert, hogy Jermy Tibor az 1960-as évek vége óta foglalkozott a növényevő rovarok és gazdanövényeik evolúciós kapcsolatával. Az ezt megelőzó években gazdag tapasztalatokat szerzett a növényevő rovarok táplálékválasztásáról, elsősorban a burgonyabogár tanulmányozásával, mely egy életen át fontos modellállata maradt. Arra a következtetésre jutott, hogy a táplálkozást stimuláló anyagok mellett kiemelkedő jelentőségüek a táplálkozást gátló növényi másodlagos anyagcseretermékek. Ezek határozzák meg a tápnövények körét, mert olyan erős hatást képesek gyakorolni, hogy a táplálkozást akár a legfontosabb, az optimális tápnövényen is megakadályozzák, ha alkalmas módszerrel ezeket a növényekre juttatják. Kiderült, hogy a normális táplálkozás fenntartásához a fagostimulánsok és -inhibítorok optimális aránya szükséges. Azokban a növényekben, melyeket egy rovar nem fogyaszt el, vagy a táplálkozását gátló anyagok vannak túlsúlyban, vagy nem szolgáltatnak olyan információkat, melyek alapján a rovar tápnövényként ismerné fel őket.

A tudománynak szüksége van alternatív hipotézisekre. Jermy Tibor a bonyolult E\&R-modell helyett egyszerü alternatív hipotézist állított fel, és alátámasztotta megfigyelésekkel, adatokkal. Azt állította, hogy a növényevő rovarok pusztán követték, de nem befolyásolták a növénygazdáik evolúcióját, mint ahogy azt az E\&R-elmélet feltételezi. Tehát nem hajtóerejei a növényi evolúciós változásoknak, bár maguk alkalmazkodnak a növényi kémiai háttér megváltozásához. A paleobotanikusok szerint a növényi evolúció autonóm, és elsősorban abiotikus hatótényezők voltak fontosak alakításában, kivéve a Kréta-kori robbanásszerü radiációt a zárvatermők esetében, melyben a beporzó rovarfajok fontos - azonban egyoldalú - szerepet játszottak.

Jermy evolúciós nézeteit első alkalommal az 1972-ben beadott MTA doktori értekezésében fogalmazta meg és ,követö evolúciónak” nevezte, utalva arra, hogy a növényevő rovarok nem voltak kiváltói a növények filogenetikai változásainak. A nemzetközi tudós közösség számára elöször subsequent evolution elnevezéssel (például 1971-ben egy Hollandiában rendezett szimpóziumelőadás címében), későbbi szakcikkeiben sequential evolution néven szerepelt.

Jermy a témával foglalkozó, nagyjából öt szakcikkben kifejtett gondolataira igen vegyes reakciókat kapott. A The American Naturalist címü tekintélyes folyóiratban 1984-ben megjelent cikke (Jermy, 1984) közel háromszáz hivatkozást kapott, melyek közül több erösen bírálta téziseit, mások lelkesedtek. Jermy természetesen érvekkel és sok példával támasztotta alá hipotézisét, melyek - a részleteket mellőzve - a következők voltak:

- tagadta, hogy a növényi másodlagos anyagcseretermékek létoka (Fraenkel [1959] kifejezésére utalva: raison d'être) a növényevő rovarok lennének. Ezek az anyagok a növényi élet megjelenése óta léteznek, és sok funkciójuk van, többek között antimikrobiális, allelopátiás stb. (Edwards, 1989). Ez 
nem zárja ki azt, hogy a rovarok képesek indukálni ezen vegyületek menynyiségét;

- a növényevő rovarok nem gyakorolnak meghatározó jelentőségủ szelektív nyomást a növényekre a táplálkozásukkal;

- a rovarok a követő evolúció során autonóm módon változnak (Jermy ezt az „intrinsic trend of diversification” kifejezéssel jelölte); a filogenetikai kapcsolatukat a növényekkel alapvetően ún. gazdaváltások (host-shifts) jelentik, melyek jóval (esetleg évmilliókkal) később valósulnak meg, és így inkongruens kladogramokat eredményeznek.

A szekvenciális evolúciót tükröző kladogramot, melyet a szakirodalomban „,forráskövetés” kifejezéssel jelölnek, élesen elkülönítik a „filogenetikai nyomkövetéstöl", amely ún. párhuzamos kladogramot eredményez, és majdnem egyidejü speciációt feltételez a két résztvevő között koevolúció nélkül (Poisot, 2015). Ilyen jellegủ például a madárfajok és tolltetveik kapcsolata, amely azonban erösen aszimmetrikus abban az értelemben, hogy az új madárfajok kialakulásakor a régi ektoparazitáik is rajtuk maradtak, és az új fajon fajképződésen mentek át. Az ugyanis egy kissé bizarr feltevés lenne, hogy a madárfajok speciációja a tolltetvek hatásaként következett be; viszont a tolltetvek evolúciója tükrözi a gazdáik evolúcióját.

Néhány fontos kiegészítést is kell tenni: Az élölények közösségeiben minden faj több (sok) kapcsolattal rendelkezik, amelyeknek csak egyike a növényevő rovar és a növény kapcsolata, és amelyek csak ritka esetben teszik lehetővé a szigorúan vett páros koevolúciót. Helyette - ha egyáltalán - a sokkal nehezebben leírható „diffúz koevolúció” uralkodhat. Minden egyes kapcsolattípust meg kell vizsgálni, hogy a szekvenciális evolúció alkalmazható-e rá. Például, az egyik fontos közösséget strukturáló hatásra, az ugyanazon forrásért folyó fajok közötti versenyre nem érvényes. Kérdés, mennyire gyakori a verseny? A ragadozó-zsákmány kapcsolat viszont erősen aszimmetrikus (az elfogott zsákmány rátermettsége nulla), de ebben az esetben csak szoros koadaptáció zajlik. A kölcsönösségi kapcsolatok is túlnyomóan aszimmetrikusak, és bár több fajtája valóban koevolúció, a növények törzsfejlődésében oly fontos szerepet játszó rovarbeporzás nem az! A növények adaptálódtak a beporzó rovarok sajátosságaihoz, és a rovarok többsége - lévén generalista viráglátogatók - egyáltalán nem. Bár a vélemények megoszlanak, jelenleg a tudós közösség arra hajlik, hogy a legelésző nagytestü gerinces növényevők koevolváltak a fúfajokkal.

A szoros értelemben vett „megszökés és radiáció” modellnek megfelelő ismert esetek száma rendkívül alacsony, a fél tucatot sem éri el az eddig megvizsgált növény-rovar kapcsolatok esetében. Ezzel szemben a szekvenciális evolúció szerint zajló kapcsolatok száma - köszönhetően elsősorban a molekuláris evolúciós és ökológiai vizsgálatoknak - egyre növekszik. (Ezek között vannak olyanok is, 
amelyek leírják a szekvenciális evolúció folyamatát, azonban - talán a szakterületet túlnyomóan uraló koevolúció nyomására - nem hivatkoznak Jermyre.) Egyre több esetben bizonyosodik be az is, hogy a két résztvevő egyidejü kapcsolata evolúciós időben nem áll fenn; a kérdéses rovarcsoport tagjai jóval később települtek rá a növényi vonalakra, ami ismét a szekvenciális evolúciót bizonyítja. Jermy nagy örömére szolgált, hogy saját kutatási eredményei alapján egy erös példát szolgálhatott elméletének bizonyítására (Jermy-Szentesi, 2003), melynek érvényességét molekuláris filogenetikai vizsgálatok is bizonyították (Kergoat et al., 2004).

Jermy Tibor magányos harcát elmélete elismertetéséért kitartóan vívta, és bár széles körben elismert tudósokkal (Douglas Futuyma, John Maynard-Smith, John N. Thompson, Elizabeth A. Bernays és mások) vitatta meg, áttörést életében nem sikerült elérnie. Ezért is nagyra értékelhetjük, hogy most egy nemzetközi tudóscsoport vállalkozott arra, hogy méltassa és megerősítse a szekvenciális evolúció jelentőségét. Ebben az értelemben azok a magyar kutatók, akik ismerték Jermy Tibor munkásságát, bizonyos fokú szégyenérzettel ismerik el, hogy nem ők, hanem külföldi kollégák kezdeményezték a szekció szervezését. Ennek oka részben az, hogy - ismerve a koevolúció híveinek hangerejét - nem remélhették, hogy jelentős részvételt eredményezett volna egy, csak a szekvenciális evolúcióval foglalkozó tudományos tanácskozás. Ez talán kishitűség volt.

Az ISCE keretében szervezett szekcióülés fontosabb előadói közül Niklas Janz (Stockholmi Egyetem) Jermy elméletét mint alternatívát, valamint a rovar-növény kapcsolat aszimmetrikus jellegét emelte ki. (Jermy az aszimmetriára már a 1980-as évek végén felhívta a figyelmet.) Emmanuelle Jousseline (Montpellier-i Egyetem) az igen bonyolult füge-fügedarázs közösség kapcsolatának problémáit mutatta be. A korábban a szoros, párhuzamos koevolúció esetének tekintett kapcsolat egyre több inkongruenciát mutat fel, amelyet számtalan beporzó és parazita fügedarázsfaj, valamint a kb. hétszáz fügefaj nem kellően tisztázott filogenetikai helyzete tesz komplexszé. John L. Maron (Montanai Egyetem) Jermy azon állítását kommentálta, hogy a növényevő rovarok nem okoznak jelentős biomassza veszteséget, ellenben a magvak fogyasztása a növényi rátermettség szempontjából kritikus. Mike C. Singer (Plymouthi és Paul Sabatier Egyetemek) valamikor Paul Ehrlich PhD-hallgatója volt. Mára eltávolodott az E\&R koevolúciós elmélettől, és Jermy hipotézise szemszögéből vizsgálta egy nappali lepkefaj gazdanövény váltásait. A faj ötven év alatt több új tápnövényen telepedett meg, amit gyors evolúciós változások tettek lehetővé. Azaz a gazdaváltás korántsem olyan ritka, mint ahogy korábban feltételezték.

Jermy munkásságát Magyarországon ismerik a legkevésbé. Igaz, sem ismeretterjesztő, sem magyar nyelvü szaklapokban nem publikálta elméletét, az MTA által kiadott Értekezések, emlékezések címü sorozat egyik füzete (Jermy, 1987) kivételével. Követője sem akadt, aki folytatta volna a munkáját. Az elméletének 
prediktáló erejét jelentősen növelte volna, ha matematikai és filogenetikai modellek készültek volna. Mindezek ellenére, a szekcióüléssel a magyar tudomány egy újabb elismerését üdvözölhetjük.

\section{IRODALOM}

Edwards, P. J. (1989): Insect Herbivory and Plant Defence Theory. In: Grubb, P. J. - Whittaker, J. B. (eds.): Towards a More Exact Ecology. Oxford: Blackwell Scientific, 275-297. https://www. researchgate.net/publication/282481832_Insect_herbivory_and_plant_defence_theory

Ehrlich, P. R. - Raven, P. H. (1964): Butterflies and Plants: A Study in Coevolution. Evolution, 18, 586-608. DOI: 10.2307/2406212, https://bit.ly/2IxyBmD

Fraenkel, G. S. (1959): The Raison d'être of Secondary Plant Substances. Science, 129, 1466-1470. DOI: 1126/science.129.3361.1466, https://science.sciencemag.org/content/129/3361/1466

Jermy T. (1984): Evolution of Insect/Host Plant Relationships. The American Naturalist, 124, 609-630. DOI: 10.1086/284302, https://www.researchgate.net/publication/221959016_Evolution_of_InsectHost_Plant_Relationships

Jermy T. (1987): Gondolatok a koevolúcióról (Akadémiai székfoglaló, 1986. március 11.). In: Tolnai M. (szerk.): Értekezések, emlékezések. Budapest: Akadémiai Kiadó

Jermy T. - Szentesi Á. (2003): Evolutionary Aspects of Host Plant Specialisation - A Study in Bruchids (Coleoptera: Bruchidae). Oikos, 101, 196-215. DOI: 10.1034/j.1600-0706.2003.11918.x, http://bruchiteam.nhmus.hu/szentesipdf/Jermy-Szentesi-Oikos.pdf

Kergoat, G. J. - Delobel, A. - Silvain, J. F. (2004): Phylogeny and Host-specificity of European Seed Beetles (Coleoptera, Bruchidae), New Insights from Molecular and Ecological Data. Molecular Phylogenetics and Evolution, 32, 855-865. DOI: 10.1016/j.ympev.2004.02.019, https:// bit.ly/2WSWGIp

Lenton, T. M. - Schellnhuber, H. J. - Szathmáry E. (2004): Climbing the Co-evolution Ladder. Nature, 431, 913. DOI: 10.1038/431913a, https://www.researchgate.net/publication/200033232 Climbing the_co-evolution_ladder

Poisot, T. (2015): When is Co-phylogeny Evidence of Coevolution? In: Morand, S. - Krasnov, B. R. - Littlewood, D. T. J. (eds.): Parasite Diversity and Diversification. Evolutionary Ecology Meets Phylogenetics. Cambridge: Cambridge University Press, 420-433. DOI: 10.1017/ CBO9781139794749.028, https://www.researchgate.net/publication/319291647_When_is_cophylogeny_evidence_of_coevolution 